\title{
Assessment Of Computer Literacy Of Secondary School Teachers In Ekiti State, Nigeria
}

James Ayodele Oluwatayo, University of Ado-Ekiti, Nigeria

\begin{abstract}
The study assessed computer literacy of secondary school teachers in Ekiti State. Three hundred teachers (Male=150; Female $=150$ ) selected from 30 public schools in 15 out of 16 local government areas participated. The instrument for collecting data was a 25-item Self-Assessment of Computer Literacy questionnaire and each item was rated on a four-point scale (Very High, High, Low and Very Low). The reliability coefficient of the instrument was estimated at 0.72 using Cronbach- $\alpha$. Data were analysed using quartile range, frequency counts, percentages, $t$-test and one-way ANOVA tested at 0.05 level of significance. Results show that teachers' computer literacy was low, sex and location had no significant influence on teachers' computer literacy, and experience had significant influence with the less experienced teachers having higher computer literacy than their average and high-experienced counterparts. It was suggested that regular workshops/seminars be organised for teachers to acquire desirable skills in computers for realisation of the objectives of computer education in Nigeria.
\end{abstract}

Keywords: Assessment; Computer Literacy; Teachers, Ekiti State

\section{INTRODUCTION}

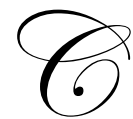

omputer literacy, in the context of this paper, is defined as the amount of knowledge and skills acquired by an individual to perform a given task using a computer system. Expectedly, the knowledge and skills acquired in this area may be very high, high, low or very low, depending on the individual's exposure to computer facilities.

Research suggests that there are many positive attributes associated with being computer literate, including an increase in ability to read, write and speak the language of the computer (Ajibade, 2006), ability to solve teaching and learning problems (Resen \& Michelle, 1995), ability to think deeply and creatively (Santrock, 2005), ability to administer, score and interpret the results of a given test (Kaplan \& Saccuzzo, 2005), and ability to develop a positive attitude and value for teaching and learning (Adomi \& Anie, 2006).

In reality, it is fruitless to consider any issue in education today without any reference to computer education. The reason being that we are in an increasingly globalised world where technologies of informational literacy and numeracy are rapidly shifting from paper, pencil and book technologies to screen, search engine and webpage. Moreover, the traditional system of testing using paper and pencil tends to give way for electronic testing. Indeed, every element of change that characterises learning in higher institutions worldwide and workplace today has important implications for computer literacy (Okebukola, 2004). Undoubtedly, students of the present age may find it hard to make a good living without being computer literate because employers of labour seem to realise that computers and other Information and Communication Technology (ICT) facilities enhance efficiency and productivity. For example, in a promotion interview conducted on Monday, January 17, 2011, by the University of Ado-Ekiti, Nigeria, for the post of Deputy Registrar, the knowledge of computer was demanded. It is clear, then, that an individual without computer education might find it difficult to excel. 
An attempt to popularise computer education in Nigeria evolved in 1988 when the Nigerian Federal Government launched the National Policy on Computer Literacy at primary, secondary and tertiary levels of education with the aim of equipping the individual or student with a thorough understanding of the concept of computers in order to fit into the next century (Okebukola, 1997). The objectives of the programme, as contained in the address of the then Federal Minister of Education, Professor Jubril Aminu, to the Ad-hoc Committee on Computer Literacy in Nigeria (1998) are to:

1. Bring about a computer literacy society in Nigeria within a short period of time

2. Enable the present generation of school children at all levels to appreciate the potentials of the computer and to enable them to be able to use the computer in various aspects of life and later occupations

Subsequently, the state governments throughout Nigeria embraced the policy of the Federal Government by introducing computer education and literacy into secondary schools in 1997 (Bada, Ajibade \& Ojedokun, 2009, and Adomi \& Kpangban, 2010). The general objectives of the programme are to:

1. Bring about computer literacy in each state in Nigeria

2. Develop the use of computers as a teaching tool in all subject areas and to familiarise students with the use of computer technology

3. Enable the present generation of school children at the secondary school level to appreciate the potentials of the computer and to be able to utilise the computer in various aspects of life and later occupations

4. Expose teachers and students to the latest scientific knowledge and skills

From the foregoing, it is important to keep in mind that the computer itself does not improve students' ability to learn but it provides several essential conditions, such as unflinching support from the teachers who are expected to be skilled in the use of computers for teaching and learning, as well as access to contemporary technologies to enable both the subject teachers and students to practice and acquire the needed exposure to the latest scientific knowledge and skills. The implication, then, is that every teacher, irrespective of gender, area of specialization, qualification, year of teaching experience or location where he or she teaches, is bound to be computer literate so as to use the device as a teaching tool in his or her subject area and be able to familiarise students with the use of computer technology. The question then arises, "Are the present generation of teachers in Nigerian secondary schools computer literate to implement the objectives of the computer programmes?"

Meanwhile, Bada, Ajibade \& Ojedokun (2009) pointed out that many Nigerian teachers are resistant to change because some view the use of the computer for education as a means of displacing them from their cherished jobs rather than an instructional material to enrich teaching and learning. Moreover, some teachers regard the use of the computer as an increase in their tasks in the classroom without adequate compensation. This is intriguing, though the fact remains that the chalkboard and book technologies that currently dominate classroom activities may eventually give way to electronic learning which requires adequate knowledge of the computer. Speculatively, if the teachers of the present age are reluctant to change with the computer age, the students of the present age may overtake them and render their much cherished job in the classroom irrelevant. This is likely because in peeping into the various cyber-café centres in most towns and villages in Nigeria today, one would find the youths either browsing or doing other activities using the computer, which might provide them accessibility to learning materials online.

However, it might sound illogical at this point to conclude that teachers in Nigerian secondary schools are not computer friendly, especially in Ekiti State where quality education seems to be highly cherished. It is believed that the outcome of this assessment would reveal the level of computer literacy of the teachers who are objective participants in the computer education programme.

\section{PURPOSE OF THE STUDY}

The purpose of this study was to assess computer literacy of secondary school teachers in Ekiti State as well as determining whether sex of teachers, their years of experience, and location where they teach would influence their computer literacy. 


\section{RESEARCH QUESTIONS}

The following questions were raised to guide the study:

1. What is the level of computer literacy of secondary school teachers in Ekiti State?

2. Will sex of teachers influence their computer literacy?

3. Will experience of teachers influence their computer literacy?

4. Will location of schools influence teachers' computer literacy?

\section{RESEARCH HYPOTHESES}

The following hypotheses were tested at 0.05 level of significance:

Ho $_{1}$ : Sex of teachers will not significantly influence their computer literacy.

$\mathbf{H O}_{2}$ : Experience of teachers will not significantly influence their computer literacy.

$\mathbf{H O}_{3}$ : Location of schools will not significantly influence computer literacy of the teachers.

\section{METHODOLOGY}

\section{Research Design}

The study was a survey type in order to describe the level of computer literacy of secondary school teachers in Ekiti State, Nigeria.

\section{Sample and Sampling Technique}

The sample was 300 teachers selected from 30 public secondary schools in 15 out of 16 local government areas of Ekiti State using a stratified random sampling technique. The strata recognised the sex of teachers (Male=150; Female=150) and location of schools (Urban=15; Rural=15).

\section{Research Instrument}

The instrument for collecting data was a 25 -item self-report questionnaire titled 'Self-Assessment of Computer Literacy'. Each item was rated on a four-point scale; namely, Very High $(\mathrm{VH})=4$, High $(\mathrm{H})=3$, Low $(\mathrm{L})=2$ and Very Low $(\mathrm{VL})=1$ with reliability coefficient of 0.72 using Cronbach $-\alpha(1951)$.

Sample items include:

- $\quad$ My accessibility to computer facilities is

- $\quad$ My understanding of basic functions of computer hardware components is

- $\quad$ My ability to turn on/off a computer system is

- $\quad$ My ability to create a file/folder on a computer is

- $\quad$ My ability to use Microsoft Word for word processing is

- $\quad$ My ability to save information on a computer system is

- $\quad$ My ability to retrieve information from a computer system is 
- $\quad$ My ability to access the internet using a computer system is

- $\quad$ My ability to use the computer for classroom instruction is

The instrument also contained items on teacher's sex (Male/Female), year of experience categorised as 0-5 (Low), 6-15 (Average), 16 and above (High), as well as location of school (Urban/Rural).

\section{Data Collection and Analysis}

Data were collected using research assistants and were analysed using quartile ranges, frequency counts, percentages, t-test and One-Way Analysis of Variance (ANOVA) tested at 0.05 level of significance.

\section{RESULTS}

Question 1: What is the level of computer literacy of secondary school teachers in Ekiti State?

Data were analysed using quartile ranges, frequency counts and percentages as presented in Table 1.

Table 1: Quartile Range of Scores, Frequency Counts and Percentages of Level of Teachers' Computer Literacy

\begin{tabular}{|l|c|c|c|}
\hline \multicolumn{1}{|c|}{ Level } & Quartile Range Of Scores & N & \% \\
\hline VL & $25-40$ & 83 & 27.7 \\
\hline L & $41-60$ & 115 & 38.3 \\
\hline H & $61-80$ & 71 & 23.7 \\
\hline VH & $81-100$ & 31 & 10.3 \\
\hline
\end{tabular}

Minimum score $=25$, Maximum score $=100$

Table 1 shows that 83 teachers representing $27.7 \%$ had very low computer literacy, 115 representing $38.3 \%$ had low computer literacy, 71 representing $23.7 \%$ had high computer literacy, while 31 representing $10.3 \%$ had very high computer literacy. These results show that $66 \%$ of the teachers had either very low or low computer literacy, while $34 \%$ had either high or very high computer literacy.

\section{Testing of Hypotheses}

HO$_{1}$ : Sex of teachers will not significantly influence their computer literacy

Data were analysed using a t-test comparison as presented in Table 2.

Table 2: t-Test Comparison between Male and Female Teachers' Computer Literacy

\begin{tabular}{|c|c|c|c|c|c|c|}
\hline Variables & $\mathbf{N}$ & Mean & SD & df & $\mathbf{t}_{\mathrm{cal}}$ & $\mathbf{t}_{\mathrm{tab}}$ \\
\hline Male & 150 & 54.7 & 16.6 & \multirow[b]{2}{*}{298} & \multirow[b]{2}{*}{0.871} & \multirow[b]{2}{*}{1.96} \\
\hline Female & 150 & 56.5 & 19.1 & & & \\
\hline
\end{tabular}

$\mathrm{P}>0.05$ (not significant)

Table 2 shows that the mean scores for male and female teachers in self-assessment of computer literacy were 54.7 and 56.5, respectively, while the t-test comparison was 0.871 and its corresponding table value at 0.05 level of significance was 1.96. Since $\mathrm{t}_{\mathrm{cal}}<\mathrm{t}_{\mathrm{tab}}$, it implies that sex of teachers had no significant influence on their computer literacy.

$\mathbf{H O}_{2}$ : Experience of teachers will not significantly influence their computer literacy

Data were analysed using One-Way Analysis of Variance and its summary is as presented in Table 3. 
Table 3: One-Way ANOVA Summary, Experience of Teachers versus Computer Literacy

\begin{tabular}{|c|c|c|c|c|c|}
\hline Source of Variation & SS & df & Mss & $\mathbf{F}_{\mathrm{cal}}$ & $\mathbf{F}_{\mathrm{tab}}$ \\
\hline Between group & 23007.11 & 2 & 1153.6 & \multirow[b]{3}{*}{$3.66^{*}$} & \multirow[b]{3}{*}{3.04} \\
\hline Within group & 93622.04 & 297 & 315.2 & & \\
\hline Total & 95929.15 & 299 & & & \\
\hline
\end{tabular}

$* \mathrm{P}<0.05$ (significant result)

Table 3 shows that the F-calculated was 3.66 while its corresponding table value was 3.04 at 0.05 level of significance. These results show that experience had significant influence on teachers' computer literacy. The posthoc analysis using a Scheffe test is as presented in Table 4.

Table 4: Post-Hoc Analysis on Teachers' Experience using Scheffe Test

\begin{tabular}{|l|c|c|c|c|c|}
\hline \multicolumn{1}{|c|}{ Variables } & LE & AE & HE & Mean & N \\
\hline $0-5$ & & & & 57.3 & 79 \\
Low Experience (LE) & & & $*$ & 56.6 & 145 \\
\hline 6-15 & & & & 50.6 & 76 \\
\hline $\begin{array}{l}\text { Average Experience (AE) } \\
\text { High Experience (HE) }\end{array}$ & $*$ & & & \\
\hline
\end{tabular}
$* \mathrm{P}<0.05$

Table 4 shows that significant influence of experience exists between computer literacy of low and high experienced teachers as well as average and high experienced teachers, with the low experienced teachers having the highest computer literacy.

$\mathbf{H O}_{3}$ : Location of schools will not significantly influence computer literacy of teachers.

Data were analysed using a t-test comparison as presented in Table 5.

Table 5: t-test Comparison between Computer Literacy of Teachers in Urban and Rural Areas

\begin{tabular}{|l|c|c|c|c|c|c|}
\hline \multicolumn{1}{|c|}{ Variables } & N & Mean & SD & df & $\mathbf{t}_{\text {cal }}$ & $\mathbf{t}_{\text {tab }}$ \\
\hline Urban & 150 & 55.05 & 18.14 & & & \\
\\
\hline Rural & 150 & 55.97 & 17.71 & 298 & 0.440 & 1.96 \\
\hline
\end{tabular}

$\mathrm{P}>0.05$ (not significant)

Table 5 shows that the mean scores for teachers in urban and rural schools in self-assessment of computer literacy were 55.05 and 55.97, respectively, while the t-test calculated was 0.440 and its corresponding table value was 1.96 at 0.05 level of significance. These results show that location of schools had no significant influence on computer literacy of the teachers.

\section{DISCUSSION}

The results in Table 1 show a discouraging level of computer literacy as $66 \%$ of the respondents rated their knowledge and skills in performing specific tasks using the computer as either low or very low. This result corroborates the previous finding of the New Partnership for Africa's Development (NEPAD, 2003) in Adomi \& Kpangban (2010) that $75 \%$ of teachers in African schools, including Nigeria, have no or very limited experience and expertise regarding Information and Communication Technology (ICT) educational applications. The results also tally with the report of Bada, Ajibade \& Ojedokun (2009) that many teachers in Nigerian schools are resistant to the use of computers for instructional purposes on the assumption that it would displace them from their much cherished jobs. 
This is disappointing because the inability of the teachers to acquire the needed knowledge and skills to operate a computer effectively might hinder the realisation of the objectives of computer education in Ekiti State. However, one should not lose sight of the fact that the majority of the teachers reported their inaccessibility to computer facilities which might have been responsible for low or very low computer literacy. Previous studies in the area of persistent problems militating against computer education and application in Nigeria identified, among others, the unavailability of computers (Enakrire \& Onyenenia, 2007), frequent electricity interruptions (Adomi \& Kpangban, 2010), exorbitant price of software and maintenance (Bada, Ajibade \& Ojedokun, 2009) and the dearth of trained personnel to use computers for instruction (Kaku, 2005). Notwithstanding, it is expected, from the angle of pragmatism, that if the teachers develop a personal interest and self-development in computer education, much incursion would be made in the acquisition of computer literacy to solve teaching and learning problems even more rapidly and accurately than envisaged.

The results in Table 2 show no significant influence of sex on computer literacy of the teachers as the t-test calculated (0.871) was less than the table value of 1.96 at 0.05 level of significance. The range of scores for males (38.1 to 71.3) and females (37.4 to 75.1) were similar and within the range of very low and high computer literacy, which tends to reinforce the findings in Table 1. Though significant influence of sex on teachers' computer literacy could not be established, the mean score of female teachers (56.5) was higher than the males (54.7), which could be attributed to the nature of the instrument which allowed for self-assessment.

The results in Tables 3 and 4 show significant influence of experience on computer literacy of the teachers, with the less and average experienced teachers having higher computer literacy than the highly experienced teachers. This is not surprising because the less and average experienced teachers entered into the teaching field at a time when the nation was clamouring for computer literacy at all levels of the educational system. That might have presumably motivated some of the teachers to learn the rudiments of the computer compared to the highly experienced ones whose desire for computer literacy might be low as reflected in the results of this study.

The results in Table 5 show no significant influence of location on computer literacy of the teachers, indicating that irrespective of where the teachers teach, it is of no significant influence on their computer literacy. This is surprising because ordinarily one would expect teachers in the urban areas to be more computer literate than their counterparts in the rural areas due to their exposure and availability of private cyber cafés in urban areas. However, the result was to the contrary. More surprisingly, the mean score of teachers in the rural areas (55.97) was slightly higher than those in the urban areas (55.05). Causal observation revealed that most teachers teaching in the rural areas reside in urban towns because of easy mobility, which could have made the slight difference in the mean scores a mere chance.

\section{CONCLUSION}

It could be concluded in this study that computer literacy of secondary school teachers in Ekiti State was low and that teachers' sex and location where they teach had no significant influence on their computer literacy, while the less experienced teachers had higher computer literacy than their average and high experienced teachers.

\section{RECOMMENDATIONS}

Based on the findings and conclusion of this study, the following recommendations were made:

1. The Government of Ekiti State should make computer facilities accessible to teachers to learn and practice so as to use the device as a teaching tool in all subject areas and to familiarise students with the use of computer technology.

2. The teachers should create sound interest and self-development in computer education so as to push backward the frontier of ignorance and advance the frontier of knowledge to enhance their job security in the classroom.

3. Stakeholders in computer education should organise regular workshops/ seminars for all categories of teachers in the secondary schools to acquire the needed skills for strengthening teaching and learning in the classroom. 


\section{AUTHOR INFORMATION}

Dr. James Ayodele Oluwatayo is a Senior Lecturer in the Institute of Education, University of Ado-Ekiti, Nigeria. His areas of teaching and research are tests and measurement, as well as Science Education. He has conducted numerous studies and published several articles in reputable journals in those areas, both locally and internationally. $\mathrm{He}$ is a member of the Nigerian Association for Educational Researchers and Evaluators (NAERE) and Mathematical Association of Nigeria (MAN). E-mail: ayotayor@yahoo.com.

\section{REFERENCES}

1. Adomi, E. E. \& Anie, S. O. (2006). An assessment of computer literacy skills of professionals in Nigerian university libraries. Library Hi Tech News. 23(2): 10-14.

2. Adomi, E. E. \& Kpangban, E. (2010). Application of ICTs in Nigerian secondary schools. href=http://www.thefreelibrary.com, retrieved April 2011.

3. Ajibade, A. (2006). Effects of interactive instructional compact disc package on the performance of English language learners in schools of science in Osun State. An unpublished Ph.D. dissertation. Obafemi Awolowo University, Ile-Ife.

4. Bada, T.; Ajibade, A. \& Ojedokun, O. (2009). Uses of computer and its relevance to teaching and learning in Nigerian educational system. Educational Research and Review. 4(10): 443-447.

5. $\quad$ Cronbach, L. J. (1951). Coefficient alpha and the internal structure of tests. Psychonetrika. 16: 297-334.

6. Enakrire, R. \& Onyenenia, O. G. (2007). Factors affecting the development of information infrastructure in Africa. Library High Tech News. 24(2): 15-20.

7. Federal Government of Nigeria (1988). Nigerian national Computer Policy. Lagos: Nigerian Tribune. April 11.

8. Kaku, F. A. (2005). The use of internet by secondary school teachers in the rural areas of Delta State: The cases of Udu local government area. Abraka: Delta State University, An unpublished B.Sc. (Lis) project.

9. Kaplan, R. M. \& Saccuzzo, D. P. (2005). Psychological testing, principles, applications and issues. Wadsworth: Thompson Learning Inc. USA. 437-449.

10. Khan, A. S. (2010). Digital literacy. The criteria for being Education Information Society. Global Journal of Computer Science Technology. Computer research org/stpf/indexph.dgjcst/article/viewfile/369/336. Retrieved February 2011.

11. New Partnership for Africa's Development (NEPAD) (2003). e-school, initiative in Africa. African Summit of the World Economic Forum. Durbar, South Africa. June.

12. Okebukola, P. (1997). Old, new and current technology in education. UNESCO Africa. 14(15): 7-18.

13. Okebukola, P. (2004). e-learning in varsities, others underway, NUC boss list strategies. The Guardian; 12th October. 35, 39.

14. Resen, L. E. \& Michelle, W. M. (1995). Computer availability, computer experience and technophobia among public school teachers. Computer in Human Behaviour. 11:9-31.

15. Santrock, J. W. (2005). Adolescence. New Delhi: McGraw-Hill, Higher Education. 10 ${ }^{\text {th }}$ edition. 491-494. 
NOTES 